Artikel Penelitian

\title{
Hubungan Sikap dan Pengetahuan Ibu Terhadap Kejadian Stunting pada Anak Baru Masuk Sekolah Dasar di Kecamanatan Nanggalo
}

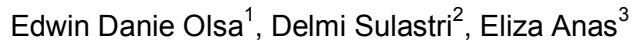

\begin{abstract}
Abstrak
Stunting adalah gangguan pertumbuhan linear tubuh anak menjadi pendek atau sangat pendek yang didasarkan pada tinggi badan menurut umur dengan ambang batas (Z-score) < - 2 SD. Salah satu faktor penting kejadian stunting merupakan pola asuh. Peranan polah asuh dari ibu dapat ditentukan dari sikap dan pengetahuan ibu yang akan membentuk perilaku pola asuh. Tujuan penelitian ini adalah untuk memperoleh informasi tentang hubungan antara sikap dan pengetahuan ibu terhadap kejadian stunting pada anak baru masuk sekolah dasar. Metode yang digunakan adalah studi cross sectional. Subjek penelitian berjumlah 232 anak baru masuk sekolah dasar usia 6-7 tahun dan ibu di Kecamatan Nanggalo Kota Padang. Subjek penelitian yang sudah menyetujui inform consent, akan mengisi kuesioner dan dilakukan pengukuran tinggi badan. Data akan dianalisis dengan menggunakan chi-square. Hasil penelitian ini didapatkan angka kejadian stunting pada anak baru masuk sekolah dasar sebesar 16,8\%, sebagian besar ibu memiliki tingkat sikap positif $(55,2 \%)$ dan tingkat pengetahuan yang cukup $(48,7 \%)$. Berdasarkan analisis bivariat antara sikap dan kejadian stunting diketahui nilai $p<0,05(p=0,000)$, serta antara tingkat pengetahuan dan kejadian stunting diketahui nilai $p<0,05(p=0,000)$. Hasil penelitian ini menunjukkan bahwa ada hubungan yang bermakna antara sikap dan pengetahuan ibu dengan kejadian stunting pada anak baru masuk sekolah dasar di Kecamatan Nanggalo Kota Padang.
\end{abstract}

Kata Kunci: stunting, anak baru masuk sekolah dasar, pengetahuan, sikap, ibu

\begin{abstract}
Stunting is a linear growth retardation where children have shorter or very short stature based on height for age according to the threshold of (Z-score) <-2 SD. One of the important factor of stunting incident is parenting. Parenting can be determined by maternal knowledge level and attitude that create parenting behavior. The objective of this study was to get information about the relationship between knowledge level and maternal attitude on stunting incident among new elementary students. The method used was a cross sectional study. The subjects are 232 new elementary students aged 6-7 years old and their mother in Nanggalo Subdistrict of Padang City. The subject of research that has been approved informed consent, will fill out a questionnare and measure height. The data was analyzed using chisquare. The result of this study showed $16.8 \%$ new elementary students had stunting. Children with positif attitude level (55.2\%) and sufficient knowledge level (48.7\%). Based on the bivariate analysis between attitude and stunting incident, $p$ value was $p<0.05(p=0.000)$. Based on the bivariate analysis between knowledge and stunting incident $p$ value was $p<0.05(p=0.000)$. The results of this research indicate that, there was a significant relationship between knowledge level and maternal attitude of new elementary school children in Nanggalo Subdistrict of Padang City.

Key words: stunting,new elementary student , knowledge, attitude,mother
\end{abstract}

Affiliasi penulis: 1. Prodi Profesi Dokter FK Unand (Fakultas Kedokteran Universitas Andalas Padang), 2.Bagian IImu Gizi FK Unand, 3.Bagian Biologi FK Unand
Korespondensi: Edwin Danie Olsa,

Email: edwin.sman4@gmail.com, Telp: 085365049320 


\section{PENDAHULUAN}

Stunting didefinisikan sebagai keadaan tubuh yang pendek atau sangat pendek yang didasarkan pada indeks Panjang Badan menurut Umur (PB/U) atau Tinggi Badan menurut Umur (TB/U) dengan ambang batas (z-score) antara -3 SD sampai dengan $<-2$ SD. ${ }^{1}$ Stunting pada anak merupakan hasil jangka panjang konsumsi kronis diet berkualitas rendah yang dikombinasikan dengan morbiditas, penyakit infeksi dan masalah lingkungan. ${ }^{2}$

Menurut laporan The Lancet's pada tahun 2008, di dunia terdapat 178 juta anak berusia kurang dari lima tahun (balita) yang stunting dengan luas mayoritas di South-Central Asia dan sub-Sahara Afrika. Prevalensi balita stunting pada tahun 2007 di seluruh dunia adalah $28,5 \%$ dan di seluruh negara berkembang sebesar $31,2 \%$. Benua Asia memiliki prevalensi balita stunting sebesar $30,6 \%$. Prevalensi balita stunting di Asia tenggara adalah 29,4\%, lebih tinggi dibandingkan dengan Asia Timur (14,4 \%) dan Asia Barat $(20,9 \%)^{3}$

Berdasarkan data Riset Kesehatan Dasar (Riskesdas) pada tahun 2013 diketahui bahwa prevalensi kejadian stunting secara nasional adalah $37,2 \%$. Berdasarkan prevalensi nasional, dari 34 provinsi di Indonesia, Sumatera Barat berada pada urutan ke-17 (>40\%). ${ }^{4}$ Di Kota Padang angka tertinggi kejadian stunting berada di Kecamatan Nanggalo yakni sebesar $24,33 \% .^{5}$

Anak stunting berisiko mengalami peningkatan kesakitan dan kematian, terhambatnya perkembangan motorik dan mental ,penurunan intelektual dan produktivitas, peningkatan risiko penyakit degeneratif, obesitas serta lebih rentan terhadap penyakit infeksi. ${ }^{6,7}$ Stunting pada anak sekolah dasar merupakan manifestasi dari stunting pada masa balita yang mengalami kegagalan dalam tumbuh kejar (catch up growth), defisiensi zat gizi dalam jangka waktu lama, serta adanya penyakit infeksi.

Stunting tidak hanya disebabkan oleh satu faktor tetapi disebabkan oleh banyak faktor yang saling berhubungan satu dengan lain. ${ }^{8}$ Diantara faktor yang mempengaruhi kejadian stunting, pola asuh memegang peranan penting terhadap terjadinya gangguan pertumbuhan pada anak. Pola asuh yang buruk dapat menyebabkan masalah gizi di masyarakat.

Peranan orang tua terutama ibu sangat penting dalam pemenuhan gizi anak karena anak membutuhkan perhatian dan dukungan orang tua dalam menghadapi pertumbuhan dan perkembangan yang sangat pesat. Untuk mendapatkan gizi yang baik diperlukan pengetahuan gizi yang baik dari orang tua agar dapat menyediakan menu pilihan yang seimbang. ${ }^{9}$ Tingkat pengetahuan gizi seseorang berpengaruh terhadap sikap dan perilaku dalam pemilihan makanan

Seorang ibu yang memiliki pengetahuan dan sikap gizi yang kurang akan sangat berpengaruh terhadap status gizi anakya dan akan sukar untuk memilih makanan yang bergizi untukanak dan keluarganya.

\section{METODE}

Penelitian analitik observasional dengan pendekatan cross-sectional ini dilakukan di SDN 05, 08, 09, 13, 15, dan 16 Surau Gadang serta SDN 06 dan 18 Kampung Lapai Kecamatan Nanggalo Kota Padang pada bulan Januari sampai dengan Desember 2016. Teknik pengambilan sampel menggunakan simple random sampling dan didapatkan 232 responden yang terdiri dari ibu dan anak baru masuk sekolah dasar berusia 6-7 tahun. Ibu sebagai responden diwawancarai secara langsung dengan menggunakan kuesioner. Kejadian stunting pada anak diukur dengan indikator Tinggi Badan/Umur (TB/U) dan diinterpretasikan berdasarkan tabel World Health Organization - National Centre for Health Statistics (WHO-NCHS). Data yang didapat diolah menggunakan program aplikasi komputer. Analisis bivariat menggunakan chi-square.

\section{HASIL}

Tabel 1 menunjukkan bahwa frekuensi umur ibu terbanyak ditemukan pada kelompok umur 30-39 tahun yaitu sebanyak 147 orang $(63,4 \%)$. Sebagian besar ibu tidak bekerja atau sebagai ibu rumah tangga yaitu sebanyak 182 orang $(78,4 \%)$. 
Tabel 1. Distribusi frekuensi karakteristik ibu subjek penelitian

\begin{tabular}{lcc}
\hline Variabel & $\mathbf{f}$ & $\%$ \\
\hline Umur Ibu & 23 & 9,9 \\
- 20-29 tahun & 147 & 63,4 \\
- 30-39 tahun & 58 & 25 \\
- 40-49 tahun & 4 & 1,7 \\
- 50-59 tahun & & \\
Pekerjaan Ibu & 182 & 78,4 \\
- Tidak bekerja/rumah tangga & 0 & 0 \\
- Petani & 2 & 0,9 \\
- Buruh & 24 & 10,3 \\
- PNS/pegawai swasta & 22 & 9,5 \\
- Wiraswasta & 2 & 0,9 \\
- Dan lain-lain & & \\
Tingkat Pendidikan Ibu & 2 & 0,9 \\
- Tidak sekolah/tidak tamat SD & 8 & 3,4 \\
- Tamat SD/MI/sederajat & 32 & 13,8 \\
- Tamat SLTP/sederajat & 130 & 56 \\
- Tamat SLTA/sederajat & 60 & 25,9 \\
- Tamat PT/sederajat & & \\
Jumlah Anak & 136 & 58,6 \\
- 1-2 anak & 14 & 65,3 \\
- 3-4 anak & & \\
- 2 5 anak & & \\
\hline
\end{tabular}

Mayoritas tingkat pendidikan ibu adalah tamat SLTA/sederajat yaitu sebanyak 130 orang (56\%). Sebagian besar ibu memiliki 2 orang anak yaitu sebanyak 136 orang $(58,6 \%)$.

Tabel 2. Distribusi frekuensi karakteristik subjek penelitian

\begin{tabular}{lcc}
\hline Variabel & $\mathbf{f}$ & $\%$ \\
\hline Jenis Kelamin & 123 & 53,2 \\
- Laki-laki & 109 & 46,98 \\
- Perempuan & & \\
Umur & 206 & 88,8 \\
- 6 Tahun & 26 & 11,2 \\
- 7 Tahun & & \\
\hline
\end{tabular}

Tabel 2 menunjukkan bahwa sebagian besar frekuensi jenis kelamin anak adalah berjenis kelamin laki-laki yaitu sebanyak 123 anak $(53,2 \%)$ dan sebagian besar anak berada pada kelompok umur 6 tahun yaitu sebanyak 206 anak $(88,8 \%)$.
Tabel 3. Distribusi frekuensi kejadian stunting

\begin{tabular}{ccc}
\hline Stunting & $\mathbf{f}$ & $\mathbf{\%}$ \\
\hline Normal & 193 & 83,2 \\
Stunting & 39 & 16,8 \\
\hline Total & 232 & 100 \\
\hline
\end{tabular}

Tabel 3 menunjukkan bahwa sebagian besar responden memiliki tinggi badan kategori normal yaitu 193 orang $(83,2 \%)$.

Tabel 4. Distribusi frekuensi tingkat sikap ibu

\begin{tabular}{ccc}
\hline Sikap & $\mathbf{f}$ & $\%$ \\
\hline Negatif & 104 & 44,8 \\
Positif & 128 & 55,2 \\
\hline Total & 232 & 100 \\
\hline
\end{tabular}

Tabel 4, menunjukkan bahwa sebagian besar responden memiliki tingkat sikap Positif yaitu 128 orang $(55,2 \%)$.

Tabel 5. Distribusi frekuensi tingkat pengetahuan ibu

\begin{tabular}{ccc}
\hline Pengetahuan & $\mathbf{f}$ & \% \\
\hline Baik & 59 & 25,4 \\
Cukup & 113 & 48,7 \\
Kurang & 60 & 25,9 \\
\hline Total & 232 & 100
\end{tabular}

Tabel 5 menunjukkan bahwa responden memiliki tingkat pengetahuan yang cukup yaitu 113 orang $(48,7 \%)$.

Tabel 6. Hubungan sikap ibu dengan stunting pada subjek penelitian

\begin{tabular}{|c|c|c|c|c|c|}
\hline \multirow{3}{*}{ Sikap } & \multicolumn{4}{|c|}{ Status Gizi } & \multirow{3}{*}{$\mathbf{p}$} \\
\hline & \multicolumn{2}{|c|}{ Stunting } & \multicolumn{2}{|c|}{ Normal } & \\
\hline & $\mathbf{n}$ & $\%$ & $\mathbf{n}$ & $\%$ & \\
\hline Negatif & 33 & 31,7 & 71 & 68,3 & \multirow{3}{*}{0,000} \\
\hline Positif & 6 & 4,7 & 122 & 95,3 & \\
\hline Total & 39 & 16,8 & 193 & 83,2 & \\
\hline
\end{tabular}

Berdasarkan Tabel 6 dapat dilihat bahwa persentase anak baru masuk sekolah dasar yang mengalami stunting paling banyak pada anak dengan tingkat sikap ibu yang negatif yaitu sebesar $31,7 \%$ 
dibandingkan dengan anak yang memiliki tinggi badan normal paling banyak pada anak dengan tingkat sikap ibu yang positif/baik yaitu sebesar 95,3\%.

Hasil uji statistik dengan menggunakan uji chisquare menunjukkan nilai $p=0,000 \quad(p<0,05)$. Berdasarkan hasil tersebut dapat disimpulkan bahwa terdapat hubungan yang bermakna antara tingkat sikap ibu dengan kejadian stunting pada anak baru masuk sekolah dasar di Kecamatan Nanggalo Kota Padang.

Tabel 7. Hubungan pengetahuan ibu dengan stunting pada subjek penelitian

\begin{tabular}{cccccc}
\hline & \multicolumn{4}{c}{ Status Gizi } & p \\
\cline { 2 - 5 } Pengetahuan & \multicolumn{2}{c}{ Stunting } & \multicolumn{2}{c}{ Normal } \\
\cline { 2 - 5 } & $\mathbf{n}$ & $\%$ & $\mathbf{n}$ & $\%$ & \\
\cline { 2 - 5 } Baik & 1 & 1,7 & 58 & 98,3 & \\
\cline { 2 - 5 } Cukup & 10 & 8,8 & 103 & 91,2 & 0.000 \\
\hline Kurang & 28 & 46,7 & 32 & 53,3 & \\
\hline Total & 39 & 16.8 & 193 & 88,2 &
\end{tabular}

Berdasarkan Tabel 7 dapat dilihat bahwa persentase anak baru masuk sekolah dasar yang mengalami stunting paling banyak pada anak dengan tingkat pengetahuan ibu yang kurang yaitu sebesar $46,7 \%$ dibandingkan dengan anak yang memiliki tinggi badan normal paling banyak pada anak dengan tingkat pengetahuan ibu yang cukup yaitu sebesar $91,2 \%$.

Hasil uji statistik dengan menggunakan uji chisquare menunjukkan nilai $p=0,000 \quad(p<0,05)$. Berdasarkan hasil tersebut dapat disimpulkan bahwa terdapat hubungan yang bermakna antara pengetauan ibu dengan kejadian stunting pada anak baru masuk sekolah dasar di Kecamatan Nanggalo Kota Padang.

\section{PEMBAHASAN}

Hasil penelitian menunjukkan bahwa persentase tinggi anak yang tergolong normal pada anak baru masuk sekolah dasar yang berumur 6-7 tahun di Kecamatan Nanggalo Kota Padang yaitu sebesar $83,22 \%$ dan persentase anak yang tergolong stunting sebesar 16,8\%. Hasil penelitian ini lebih rendah dibandingkan dengan prevalensi stunting secara nasional $(37,2 \%)$ maupun prevalensi stunting di Sumatera Barat (>40\%), namun hasil ini lebih tinggi dibandingkan dengan prevalensi stunting di Kota Padang yaitu sebesar $15 \% .{ }^{4,5}$ Menurut Supariasa et al prevalensi stunting di Kecamatan Nanggalo Kota Padang dapat digolongkan sebagai masalah kesehatan masyarakat kategori ringan. ${ }^{10}$

Rendahnya angka kejadian stunting pada penelitian ini dapat disebabkan oleh beberapa faktor yaitu tingkat pendidikan ibu yang sudah termasuk kategori baik, pekerjaan ibu, jumlah anak dan lokasi tempat tinggal serta sikap dan pengetahuan ibu yang sebagian besar termasuk dalam kategori baik.

Pada penelitian ini sebagian besar tingkat pendidikan ibu sudah dalam kategori baik yaitu tamat SLTA/sederajat sebesar $56 \%$ dan tamat PT/sederajat sebesar $25,9 \%$. Menurut Sulastri tingkat pendidikan ibu akan mempengaruhi kesehatan dan kesejahteraan anak sehingga hal ini akan mempengaruhi status gizi anak. ${ }^{11}$ lbu dengan tingkat pendidikan yang tinggi akan lebih mudah menyerap informasi jika dibandingkan dengan ibu yang kurang atau tidak berpendidikan, sehingga dengan tingkat pendidikan yang cukup diharapkan seorang ibu mau dan mampu untuk berprilaku yang baik dalam rangka memperbaiki keadaan gizi anaknya. Hal ini didukung oleh penelitian yang dilakukan oleh Picauly dan Magdalena, di Kupang dan Sumba Timur, NTT. Menunjukkan bahwa ibu dengan tingkat pendidikan rendah memiliki peluang anaknya mengalami stunting sebesar 0,049 kali lebih besar dibanding kan dengan ibu yang memiliki pendidikan tinggi. berpengaruh pada peluang terjadinya stunting. ${ }^{12}$

Pada penelitian ini diketahui bahwa sebagian besar responden ibu adalah ibu rumah tangga yaitu sebesar $78,4 \%$. Selain itu, sebagian besar responden ibu memiliki 1-2 anak yaitu sebesar $58,6 \%$ sehingga ibu memiliki lebih banyak waktu untuk memberikan perhatian kepada anaknya. Hasil ini sejalan dengan penelitian oleh Picauly dan Magdalena, di Kupang dan Sumba Timur NTT yang menunjukkan bahwa ibu yang bekerja memiliki peluang anaknya mengalami stunting lebih besar dibandingkan ibu yang tidak bekerja, dimana terjadi peningkatan kejadian stunting sebesar 3,623 pada ibu yang bekerja. ${ }^{12}$ Menurut Berg, ibu yang bekerja tidak mempunyai cukup waktu untuk 
memperhatikan makan anak yang sesuai dengna kebetuhuan dan kecukupan serta kurang perhatian dalam pengasuhan anak. ${ }^{13}$ Salimar et al keluarga yang memiliki anggota keluarga lebih dari 4 orang berpeluang 1,2 kali mempunyai anak umur sekolah (612 tahun) dengan status gizi stunting. ${ }^{14}$

Hasil penelitian menunjukkan bahwa sikap ibu sebagian besar pada kategori yang positif sebesar $55,2 \%$, sedangkan sikap ibu dengan kategori negatif sebesar 44,8\%. Hasil penelitian ini sejalan dengan peneltian yang dilakukan oleh Talitha di Kelurahan Utan Kayu Utara Jakarta Timur yang menemukan bahwa sikap ibu paling banyak pada kategori positif $81,1 \%$, sedangkan $18,9 \%$ pada ibu dengan sikap yang di kategorikan negatif. ${ }^{15}$

Penelitian lain yang dilakukan oleh Wilujeng et al pada anak usia 1-3 tahun di Desa Puton Kecamatan Diwek Kabupaten Jomban menunjukkan hal yang hampir serupa. Dalam penelitian tersebut, didapatkan bahwa sebagian besar ibu memiliki sikap yang di kategorikan positif yaitu sebesar $52 \%$ sedangkan ibu yang memiliki sikap dengan kategori negatif sebesar $48 \%{ }^{16}$

Hasil penelitian menunjukkan bahwa pengetahuan ibu sebagian besar berada pada tingkat pengetahuan yang cukup (48,7\%), sedangkan pada tingkat pengetahuan yang baik sebesar $25,4 \%$ dan tingkat pengetahuan yang kurang sebesar 25,9\%. Hasil penelitian ini sejalan dengan penelitian yang dilakukan oleh Ayuningtiasdi SDN Gedanganak 01, SDN Gedanganak 02, SDN Gedanganak 3 Kecamatan ungaran Timur dan SDN Candirejo 01, dan SDN Candirejo 02 Kecamatan Ungaran barat, Kabupaten Semarang terhadap ibu dari siswa kelas 1 menunjukkan dari 63 sampel didapatkan sebanyak 28 ibu $(44,4 \%)$ memiliki tingkat pengetahuan yang cukup, 26 ibu (41,3\%) memiliki tingkat pengetahuan yang baik dan 9 ibu (14,3\%) memiliki tingkat pengetahuan yang kurang. ${ }^{17}$

Penelitian yang dilakukan oleh Noer dan Hestuningtyas di Kecamatan Semarang Timur terhadap ibu yang memiliki anak usia $1-2$ tahun menunjukkan sebanyak $60 \%$ ibu memiliki tingkat pengetahuan yang cukup, $30 \%$ ibu memilik tingkat pemgetahuan yang kurang, dan $10 \%$ ibu memiliki tingkat pengetahuan yang kurang. ${ }^{18}$
Hasil uji statistik dengan menggunakan uji chisquare antara sikap ibu dengan kejadian stunting pada penelitian ini diperoleh nilai $p<0,05(0,00)$ maka hasil ini menunjukkan bahwa hipotesis diterima dan terdapat hubungan yang bermakna antara sikap ibu dengan kejadian stunting pada anak baru masuk sekolah dasar di Kecamatan Nanggalo. Hasil penelitian ini sejalan dengan penelitian yang dilakukan oleh Talitha di Kelurahan Utan Kayu Utara, Jakarta Timur dan penelitian Nainggolan di Bandar Lampung, yang menemukan bahwa terdapat hubungan yang signifikan antara sikap ibu dengan status gizi dengan nilai $p<0,05 .^{15,19}$

Menurut Sunaryo, sikap merupakan kesiapan merespons yang sifatnya positif atau negatif terhadap suatu objek atau situasi secara konsisten. ${ }^{20}$ Sikap merupakan kecenderungan bertindak dari individu berupa respons tertutup terhadapa stimulus ataupun objek tertentu. Sikap menunjukkan adanya kesesuaian reaksi terhadap stimulus yang sudah melibatkan faktor pendapat dan emosi seseorang. Jadi sikap bukanlah suatu tindakan ataupun aktifitas, akan tetapi merupakan sebuah kecenderungan untuk melakukan tindakan atau perilaku atau peran. ${ }^{21}$ Menurut Nursalam, sikap seseorang dapat dipengaruhi oleh beberapa faktor yaitu faktor umur, pekerjaan, pendidikan dan paritas. Jika sebagian dari responden memiliki sikap yang negatif, makan tindakan dan perilakunya akan cenderung negatif, sehingga masalah gizi pada anak akan terjadi. ${ }^{22}$

Hasil uji statistik dengan menggunakan uji chi-square antara sikap ibu dengan kejadian stunting pada penelitian ini diperoleh nilai $p<0,05(0,00)$ maka hasil ini menunjukkan bahwa hipotesis diterima dan terdapat hubungan yang bermakna antara sikap ibu dengan kejadian sttunting pada anak baru masuk sekolah dasar di Kecamatan Nanggalo. Hasil penelitian ini sejalan dengan penelitian yang dilakukan oleh Ayuningtias pada anak kelas 1 di SDN Gedanganak dan SDN Candirejo Sleman, Yogyakarta, yang menemukan bahwa terdapat hubungan yang signifikan antara sikap ibu dengan kejadian stunting dengan nilai $p<0,05^{17}$

Hal ini sejalan dengan pendapat Notoatmodjo, mengemukakan bahwa pengetahuan merupakan hasil tahu dan terjadi setelah seseorang melakukan 
penginderaan terhadap suatu objek tertentu. Penginderaan terjadi melalui panca indera manusia yakni penglihatan, pendengaran, penciuman, rasa, dan raba. Pengetahuan dapat diperoleh antara lain melalui pendidikan baik kurikuler, nonkurikuler dan ekstrakurikuler. Pengetahuan juga dapat diperoleh dari pengetahuan orang lain, seperti: mendengar, melihat langsung dan melalui alat komunikasi seperti televisi, radio, buku dan lain-lain. ${ }^{21}$

Pengetahuan sangat erat hubungannya dengan pendidikan, dimana dapat diasumsikan bahwa dengan pendidikan yang tinggi maka orang tersebut akan semakin luas pula pengetahuannya. Pendidikan yang rendah tidak menjamin seorang ibu tidak mempunyai pengetahuan yang cukup mengenai gizi keluarganya. Adanya rasa ingin tahu yang tinggi dapat mempengaruhi ibu dalam mendapatkan informasi mengenai makanan yang tepat untuk anak. ${ }^{23}$ Peningkatan pengetahuan tidak mutlak diperoleh dari pendidikan formal saja, akan tetapi dapat diperoleh melalui pendidikan non-formal. Pengetahuan seseorang tentang suatu objek mengandung dua aspek yaitu aspek aspek positif dan aspek negatif. Kedua aspek ini yang akan menentukan sikap seseorang, semakin banyak aspek positif dan dan objek yang diketahui, maka akan menimbulkan sikap makin positif terhadap objek tertentu. ${ }^{21}$

\section{SIMPULAN}

Terdapat hubungan antara sikap dan pengetahuan ibu terhadap kejadian stunting pada anak baru masuk sekolah dasar di Kecamatan Nanggalo Kota Padang.

\section{UCAPAN TERIMAKASIH}

Terima kasih kepada dosen beserta staff di Fakultas Kedokteran Universitas Andalas atas bimbingan, bantuan, dan motivasi dalam penelitian. Kepada kepala sekolah di sekolah dasar Kecamatan Nanggalo kota padangyang telah memberikan izin dalam pelaksanaan penelitian, serta kepada orang tua siswa terutama ibu yang bersedia menjadi responden dalam penelitian.

\section{DAFTAR PUSTAKA}

1. Kementerian Kesehatan. Keputusan Menteri Kesehatan Republik Indonesia No: 1995/Menkes/SK/XII/2010. Jakarta: Kementerian Kesehatan Republik Indonesia; 2011 (diunduh 19 Maret 2016) Tersedia dari: URL: HYPERLINK http://gizi.depkes.go.id/keputusan-menterikesehatan-ri-nomor-1995menkesskxii2010tentang-standar-antropometri-penilian-status-gizianaktentang-standar

2. Semba RD, de Pee S, Sun K, Sari M, Akhter N, Bloem MW. Effect of parental formal education on risk of child stunting in Indonesia and Bangladesh: a cross sectional study. The Lancet Article. 2008; 371:322-8.

3. The Lancet. The Lancet's series on maternal and child undernutrition executive summary. 2008. (diunduh 19 Maret 2016). Tersedia dari: URL: HYPERLINK http://www.thelancet.com

4. Riskesdas. Laporan hasil riset kesehatan dasar Indonesia tahun 2013. Jakarta: Departemen Kesehatan RI; 2013.(diunduh 19 Maret 2016). Tersedia dari: URL: HYPERLINK http://labdata. litbang.depkes.go.id/riset-badan-litbangkes/menuriskesnas/menu-riskesdas/374-rkd-2013

5. Dinas Kesehatan Kota Padang. Prevalensi status gizi berdasarkan hasil pemantauan status gizi Kota Padang tahun 2015. Padang: Dinas Kesehatan Kota Padang; 2014.

6. Anugraheni. Faktor resiko kejadian stunting pada anak usia 12-36 bulan di kecamatan pati (skripsi). Semarang: Universitas Diponegoro; 2012.

7. Yunitasari W. Hubungan pengetahuan sikap dan perilaku ibu tentang gizi seimbang terhadap status gizi balita usia 3 - 4 tahun di Posyandu RW 21 Kelurahan Mekarjaya Kecamatan Sukmajaya Depok(skripsi). Jakarta: Universitas Pembangunan Nasional Veteran; 2011.

8. UNICEF. Progress for children. 2007 (diunduh 19 Maret 2016) Tersedia dari: URL: HYPERLINK http://www.unicef.org/publications/files/Progress fo r Children No 6 revised.pdf

9. Devi N. Gizi anak sekolah. Jakarta: Buku Kompas; 2012. 
10. Supariasa IDN, Bakri B, Fajar, I. Penilaian Status gizi. Jakarta: EGC; 2002.

11. Sulastri D. Faktor determinan kejadian stunting pada anak usia sekolah di Kecamatan Lubuk Kilangan Kota Padang. Majalah Kedokteran Andalas. 2012;36(1):39-50.

12. Picauly I, Magdalena T, Sarci. Analisis determinan dan pengaruh stunting terhadap prestasi belajar anak sekolah di Kupang dan Sumba Timur NTT. Jurnal Gizi dan Pangan. 2013;8(1):55-62.

13. Berg A. Peranan gizi dalam pembangunan. Jakarta: Penerbit Rajawali; 1986.

14. Salimar, Kartono D, Fuada N, Setyawati B. Stunting anak usia sekolah di Indonesia menurut karakteristik keluarga. Jurnal Penelitian Gizi dan Makanan. 2013;36:121-26.

15. Talitha NR. Hubungan karakteristik, pengetahuan, dan sikap ibu terhadap status gizi anak di Posyandu RW 5 dan RW 10 Kelurahan Utan Kayu Utara Jakarta Timur (skripsi). Jakarta: Universitas Pembangunan Negara Veteran Jakarta; 2015.

16. Wilujeng $R$, Prita $K$, Domas, Supriliyah $P$. Hubungan sikap ibu dalam memberikan makanan dengan status gizi batita usia 1 - 3 tahun di Desa Puton Kecamatan Diwek Kabupaten Jombang. Jurnal Metabolisme. 2013;2(4):36-49.
17. Ayuningtias M. Hubungan karakteristik keluarga dengan kejadian stunting pada anak baru sekolah (skripsi). Semarang: Stikes Ngudi Waluyo; 2016.

18. Noer ER, Hestuningtyas TR. Pengaruh konseling gizi terhadap pengetahuan, sikap, praktik ibu dalam pemberian makan anak, dan asupan zat gizi anak stunting usia 1 - 2 tahun di Kecamatan Semarang Timur. Journal of Nutrition College. 2014;3(1):17-25.

19. Nainggolan J. Hubungan antara pengetahuan dan sikap gizi ibu dengan status gizi balita di wilayah kerja Puskesmas Rajabasa Indah Kelurahan Rajabasa Raya Bandar Lampung (skripsi). Bandar Lampung: Universitas Lampung; 2012

20. Sunaryo. Psikologi untuk keperawatan. Jakarta: EGC;2004.

21. Notoatmojo S. Promosi kesehatan dan perilaku kesehatan. Jakarta: Rineka Cipta; 2012.

22. Nursalam. Konsep dan penerapan metodologi penelitian ilmu keperawatan. Jakarta: Salemba Medika; 2008.

23. Rakhmawati NZ. Hubungan pengetahuan dan sikap ibu dalam pemberian makanan pada anak usia 12-24 bulan (skripsi). Semarang: Universitas Diponegoro; 2013. 